\title{
Pembuatan Margarin dan Baking Shortening Berbasis Minyak Sawit Merah dan Aplikasinya dalam Produk Bakery
}

\author{
Preparation of Red Palm Oil Based Margarin and Baking Shortening and Its Application in Bakery Products
}

\section{Hasrul Abdi Hasibuan ${ }^{1 *}$, Ananta Akram ${ }^{2}$, Pratiwi Putri ${ }^{2}$, Ennisa Cita Mentari ${ }^{2}$, Bella Triana Rangkuti ${ }^{2}$}

\author{
${ }^{1}$ Peneliti Pusat Penelitian Kelapa Sawit, Jl. Brigjend Katamso No. 51 Medan, Indonesia \\ ${ }^{2}$ Teknologi Hasil Pertanian, Fakultas Pertanian, Universitas Muhammadiyah Sumatera Utara, \\ Jl. Kapten Mukhtar basri No. 3, Medan 20238, Indonesia \\ *Email: hasibuan_abdi@yahoo.com
}

Tanggal submisi: 9 Januari 2018; Tanggal penerimaan: 26 Oktober 2018

\begin{abstract}
ABSTRAK
Minyak sawit merah (MSM) merupakan produk minyak sawit yang masih mempertahankan karoten (pro-vitamin A) dengan kadar tinggi. Diversifikasi MSM pada produk pangan perlu dikembangkan untuk meningkatkan gizi konsumen. Penelitian ini dilakukan untuk membuat margarin dan baking shortening dari MSM dan mengaplikasikannya dalam produk bakery. MSM yang digunakan adalah crude palm oil (CPO) ternetralisasi (MSM NPO) dan dari tandan buah segar (MSM TBS). Margarin dibuat 2 jenis yaitu grade A (MSM 100\%) dan grade B (MSM : refined bleached deodorized palm oil (RBDPO) 50:50) dan baking shortening 2 jenis yaitu grade A (MSM : refined bleached deodorized palm stearin (RBDPS) : refined bleached deodorized palm kernel oil (RBDPKO) 70:15:15) dan grade B (MSM : RBBDPO (50:50) : RBDPS : RBDPKO 70:15:15). Produk bakery yang dibuat 3 jenis yaitu roti manis, donat dan bolu gulung. Margarin dan baking shortening yang dihasilkan memiliki karoten tinggi, bilangan peroksida memenuhi standar $(<10 \mathrm{mgeq} / \mathrm{kg}$ ) namun kadar asam lemak bebas (ALB) relatif tinggi $(0,1-0,3 \%)$ dikarenakan oleh MSM memiliki kadar ALB tinggi. Roti manis, donat dan bolu gulung menggunakan margarin dan baking shortening MSM memiliki karakteristik meliputi kadar air, kadar lemak, kadar ALB, bilangan peroksida dan pengembangan adonan (kecuali donat dan bolu gulung) menyerupai produk komersial namun kadar karotennya lebih tinggi. Penerimaan panelis terhadap warna, aroma, tekstur dan rasa roti manis, donat dan bolu gulung menggunakan MSM : RBDPO (50:50) cukup tinggi daripada MSM 100\% tetapi relatif rendah dibandingkan produk komersial. Meskipun demikian, campuran MSM dan RBDPO dapat menjadi alternatif dalam peningkatan gizi produk bakery.
\end{abstract}

Kata kunci: Bakery; baking shortening; margarin; minyak sawit merah

\begin{abstract}
Red palm oil (RPO) is a palm oil product that still retains carotene (pro vitamin A) in high contents. Diversification of RPO in food products should be developed to enhance consumers' nutrition. This research was conducted to make margarine and baking shortening based on RPO and its application in baking products. The RPO used was neutralized crude palm oil (CPO) (RPO NPO) and from fresh fruit bunches (RPO FFB). Margarine was made into 2 types namely grade A (RPO 100\%) and grade B (RPO: refined bleached deodorized palm oil (RBDPO) 50:50) and baking shortening also 2 types namely grade A (RPO: refined bleached deodorized palm stearin (RBDPS): refined bleached deodorized palm kernel oil (RBDPKO) 70:15:15) and grade B (RPO: RBBDPO (50:50): RBDPS : RBDPKO 70:15:15). Bakery products were made into 3 types of sweet bread, donuts and rolls cake. The margarine and
\end{abstract}




\begin{abstract}
baking shortening that obtained have high carotene, the peroxide value fulfills the standard of $<10 \mathrm{mgeq} / \mathrm{kg}$ but high free fatty acid (FFA) about $0.1-0.3 \%$, that is caused by RPO have high FFA. The sweet breads, donuts and rolls cake using RPO-based margarine and baking shortening have moisture content, fat content, FFA content, peroxide value and volume expansion (except donuts and rolls cake) similar to commercial products, but the carotene content was higher. Preference for color, aroma, texture and flavor of sweet breads, donuts and rolls cake using RPO : RBDPO (50:50) were quite high from RPO 100\%, but lower compared to commercial products, relatively. Therefore, mixing of RPO and RBDPO can be an alternative in improving nutrition of bread products.
\end{abstract}

Keywords: Bakery; baking shortening; margarine; red palm oil

\section{PENDAHULUAN}

Minyak sawit merah (MSM) merupakan produk minyak sawit yang masih mempertahankan karoten dengan kadar yang tinggi (Alyas dkk., 2006; Ayeleso dkk., 2012). MSM belum banyak dikonsumsi oleh masyarakat Indonesia karena berwarna kemerahan dan berbau khas sementara minyak goreng yang dikonsumsi berwarna kuning pucat dan tidak berbau. Manorama (2014) telah melaporkan bahwa MSM dapat digunakan untuk menurunkan kekurangan vitamin A (KVA). Oleh karena itu, peluang pemanfaatan MSM semakin terbuka karena dapat mengurangi dan mencegah terjadinya KVA khususnya di Indonesia (Hasibuan dan Siahaan, 2014; Hasibuan, 2016).

Minyak sawit merah mengandung fitonutrien yaitu karoten sebesar 400-500 ppm (sebagai pro-vitamin A) dan vitamin E (tokoferol \& tokotrienol) sebesar 500 ppm (Alyas dkk, 2006; Hasibuan dan Siahaan, 2014). Secara umum, a- dan $\beta$-karoten diketahui berfungsi untuk mengurangi radikal bebas (Siahaan dkk., 2008; Hasibuan dan Siahaan, 2014). Selain itu, $\beta$-karoten telah intensif diinvestigasi dalam penurunan penyakit kanker. $\beta$-karoten merupakan karotenoid yang umum di dalam makanan memiliki aktivitas vitamin A tertinggi. Komponen minor ini juga dapat digunakan sebagai alternatif zat pewarna dan vitamin sintetik (Rice dan Burns, 2010) yang biasa ditambahkan pada produk margarin.

Shortening merupakan produk lemak, sementara margarin adalah produk emulsi air dalam lemak dan keduanya berbentuk setengah padat yang dapat digunakan sebagai media penggorengan, pemasakan, pembuatan roti dan pengisi pada produk confectionery (Hasibuan dkk, 2009; Sahri dan Idris, 2010; Siahaan dkk., 2013; Hasibuan dan Hardika, 2015; Hasibuan dan Magindrin., 2015). Kedua produk tersebut dapat digunakan dalam pembuatan produk bakery seperti roti manis, donat dan bolu gulung yang cukup digemari masyarakat karena enak untuk camilan, bentuknya menarik dan rasanya bervariasi.

Margarin komersial umumnya telah diperkaya dengan nutrisi dan mineral termasuk vitamin $\mathrm{A}$ dan vitamin E (Hasibuan dkk., 2009; Hasibuan dan Hardika, 2015) sedangkan shortening untuk bakery (baking shortening) tidak ditambahkan dengan bahan lain selain lemak. Fraksi-fraksi minyak sawit yang digunakan sebagai bahan baku dalam pembuatan margarin dan baking shortening adalah refined bleached deodorized palm oil (RBDPO), refined bleached deodorized palm stearin (RBDPS) dan refined bleached deodorized palm olein (RBDPOlein) (Elisabeth, 2009; Hasibuan, 2012). Ketiga jenis lemak tersebut mengandung karoten dan vitamin $\mathrm{E}$ dalam jumlah relatif rendah dibandingkan pada minyak sawit mentah (crude palm oil, CPO) (Hasibuan dan Siahaan, 2013).

Penggunaan margarin berbahan baku MSM tanpa penambahan nutrisi dan mineral sudah dilaporkan sebelumnya oleh Jatmika dalam Hasibuan (2009) dan Hasibuan dan Hardika (2015). Andarwulan dkk. (2014) telah mengaplikasikan margarin berbahan MSM dan fat powder pada produk pound cake dan roti manis. Hasibuan dan Hardika (2015), juga telah mengaplikasikan margarin dengan bahan tambahan MSM dalam pembuatan bolu gulung yang memiliki karakteristik dan penerimaan relatif sama dengan bolu gulung dari margarin komersial. Robiyansyah dkk. (2017) telah mengaplikasikan MSM dalam pembuatan biskuit kacang dengan penerimaan terhadap kesukaan rasa mendekati rasa normal. Sementara itu, pembuatan baking shortening dari MSM belum ada yang melaporkan. Oleh karena itu, penelitian ini dilakukan untuk mengkaji penggunaan MSM sebagai bahan baku utama dalam pembuatan margarin dan baking shortening serta memanfaatkannya dalam produk bakery (roti manis, donat dan bolu gulung).

\section{METODE PENELITIAN}

\section{Bahan}

Bahan yang digunakan adalah minyak sawit merah (MSM) dari netralisasi crude palm oil (CPO) (MSM NPO) (CPO yang digunakan dari pabrik kelapa sawit (PKS)) dan MSM yang diekstraksi langsung dari tandan buah segar (TBS) (MSM TBS) secara sederhana diperoleh dari 
Science Techno House (STH) Pusat Penelitian Kelapa Sawit (PPKS) Medan. Refined bleached deodorized palm oil (RBDPO), refined bleached deodorized palm stearin (RBDPS) dan refined bleached deodorized palm kernel oil (RBDPKO) diperoleh dari industri minyak goreng di Medan. RBDPO adalah fraksi CPO yang telah mengalami proses rafinasi, RBDPS adalah fraksi padat dari fraksinasi RBDPO sedangkan RBDPKO adalah fraksi minyak inti sawit yang telah dirafinasi. Bahan-bahan dalam pembuatan produk bakery diperoleh dari toko bahan kue di Medan. Bahan kimia seperti natrium hidroksida, heksan, isooktan, kalium hidroksida, phenolphthalein masing-masing pro analysis dan natrium hidroksida dan ethanol teknis diperoleh dari E. Merck di Medan.

\section{Pembuatan Margarin dan Baking Shortening dari Minyak Sawit Merah}

Margarin dan baking shortening dibuat menggunakan dua jenis MSM yaitu MSM NPO dan MSM TBS masing-masing dengan 2 grade (grade A dan grade B) sesuai formula yang disajikan pada Tabel 1 . Perbedaan grade berdasarkan penggunaan MSM baik MSM NPO dan MSM TBS, disebut grade A apabila menggunakan $100 \%$ MSM sedangkan grade $B$ menggunakan campuran MSM dan RBDPO pada nisbah 50:50. Margarin dibuat sesuai prosedur Hasibuan dan Hardika (2015) dengan mencampurkan fase lemak (minyak/lemak dan lesitin) dan fase air (air, garam, dan flavor). Sedangkan baking shortening hanya menggunakan $100 \%$ lemak. Margarin dan baking shortening dipadatkan dengan mengadopsi prosedur Hasibuan dan Hardika (2015) dan Hasibuan dan Magindrin (2015) yaitu dengan mendinginkan campuran bahan pada suhu $4{ }^{\circ} \mathrm{C}$ selama 30 menit sambil diaduk hingga homogen dan bertekstur semi padat. Bahan baku dan produk dianalisa mutunya meliputi: kadar asam lemak bebas (ALB) dengan metode titrasi menggunakan larutan natrium hidroksida, kadar air dengan metode gravimetri secara penguapan menggunakan oven, bilangan peroksida (peroxide value, PV) dengan metode titrasi menggunakan larutan natrium tiosulfat, kadar karoten dengan metode spektrofotometri menggunakan peralatan spektrofotometer UV-Vis, kandungan lemak padat menggunakan peralatan nuclear magnetic resonance dan komposisi asam lemak dengan metode kromatografi menggunakan peralatan kromatografi gas. Parameter analisa ditentukan dengan mengacu prosedur sesuai metode standar Malaysian Palm Oil Board (MPOB) (MPOB, 2004).

\section{Pembuatan Roti Manis}

Roti manis dibuat dengan formula standar yang dimiliki oleh PPKS namun margarin dan baking shortening komersial diganti menggunakan margarin dan baking shortening menggunakan MSM (MSM NPO atau MSM TBS) seperti yang disajikan pada Tabel 2. Bahan baku dicampurkan dalam mixer hingga kalis. Selanjutnya adonan difermentasi selama 15 menit dan ditimbang sebanyak $20 \mathrm{~g}$ (sebanyak 6 sampel diberi tanda dan diukur tingginya sebelum di-proofing) kemudian dilakukan proofing pada suhu $55^{\circ} \mathrm{C}$ selama 1 jam. Adonan yang telah mengembang dipanggang ke dalam oven pada suhu $150{ }^{\circ} \mathrm{C}$ selama 30 menit (sebanyak 6 sampel bertanda diukur tingginya setelah dipanggang). Roti manis dianalisa fisiko kimianya

Tabel 1. Formulasi margarin dan baking shortening kapasitas $1 \mathrm{~kg}$

\begin{tabular}{|c|c|c|c|c|c|c|c|c|}
\hline \multirow[t]{3}{*}{ Bahan } & \multicolumn{8}{|c|}{ Jumlah (g) } \\
\hline & \multicolumn{2}{|c|}{ Margarin dari MSM NPO } & \multicolumn{2}{|c|}{ Margarin dari MSM TBS } & \multicolumn{2}{|c|}{$\begin{array}{l}\text { Baking shortening dari MSM } \\
\text { NPO }\end{array}$} & \multicolumn{2}{|c|}{$\begin{array}{l}\text { Baking shortening dari MSM } \\
\text { TBS }\end{array}$} \\
\hline & Grade A & Grade B & Grade A & Grade B & Grade A & Grade B & Grade A & Grade B \\
\hline MSM NPO & 814,5 & 407,25 & - & - & 700 & 350 & - & - \\
\hline MSM TBS & - & - & 814,5 & 407,25 & - & - & 700 & 350 \\
\hline RBDPO & - & 407,25 & - & 407,25 & - & 350 & - & 350 \\
\hline RBDPS & - & - & - & - & 150 & 150 & 150 & 150 \\
\hline RBDPKO & - & - & - & - & 150 & 150 & 150 & 150 \\
\hline Air & 158,0 & 158,0 & 158,0 & 158,0 & - & - & - & - \\
\hline Garam & 23,5 & 23,5 & 23,5 & 23,5 & - & - & - & - \\
\hline Lesitin & 3,0 & 3,0 & 3,0 & 3,0 & - & - & - & - \\
\hline Flavor & 1,0 & 1,0 & 1,0 & 1,0 & - & - & - & - \\
\hline
\end{tabular}

Keterangan: MSM NPO = minyak sawit merah dari netralisasi CPO, MSM TBS = minyak sawit merah dari tandan buah segar, RBDPO = refined bleached deodorized palm oil, RBDPS = refined bleached deodorized palm stearin, RBDPKO = refined bleached deodorized palm kernel oil 
Tabel 2. Formulasi roti manis $(1 \mathrm{~kg})$ menggunakan margarin dan baking shortening MSM

\begin{tabular}{|c|c|c|c|c|c|}
\hline $\begin{array}{l}\text { Bahan adonan roti manis } \\
\text { Bahan adonan roti manis }\end{array}$ & $\begin{array}{l}\text { Formula } 1 \text { (kontrol) } \\
\text { formula PPKS }\end{array}$ & $\begin{array}{l}\text { Formula } 2 \\
\text { formula PPKS }\end{array}$ & $\begin{array}{l}\text { Formula } 3 \\
\text { formula PPKS }\end{array}$ & $\begin{array}{l}\text { Formula } 4 \\
\text { formula PPKS }\end{array}$ & $\begin{array}{l}\text { Formula } 5 \\
\text { formula PPKS }\end{array}$ \\
\hline Margarin komersial (g) & 15 & - & - & - & - \\
\hline Margarin MSM NPO grade A (g) & - & 15 & - & - & - \\
\hline Margarin MSM NPO grade B (g) & - & - & 15 & - & - \\
\hline Magarin MSM TBS grade A (g) & - & - & - & 15 & - \\
\hline Margarin MSM TBS grade B $(\mathrm{g})$ & - & - & - & - & 15 \\
\hline Baking shortening komersial (g) & 37,5 & - & - & - & - \\
\hline Baking shortening MSM NPO grade A ( $\mathrm{g}$ ) & - & 37,5 & - & - & - \\
\hline Baking shortening MSM NPO grade B $(\mathrm{g})$ & - & - & 37,5 & - & - \\
\hline Baking shortening MSM TBS grade A (g) & - & - & - & 37,5 & - \\
\hline Baking shortening MSM TBS grade B (g) & - & - & - & - & 37,5 \\
\hline
\end{tabular}

Keterangan: singkatan dapat dilihat pada Tabel 1

meliputi kadar air, kadar lemak, ALB, PV dan kadar karoten dengan mengacu pada metode standar MPOB (MPOB, 2004) serta uji organoleptik.

\section{Pembuatan Donat}

Donat dibuat dengan formula standar yang dimiliki oleh PPKS namun margarin dan baking shortening komersial diganti menggunakan margarin dan baking shortening menggunakan MSM (MSM NPO atau MSM TBS) seperti yang disajikan pada Tabel 3. Bahan baku dicampurkan dalam mixer hingga kalis. Selanjutnya adonan difermentasi selama 15 menit dan ditimbang sebanyak $20 \mathrm{~g}$ (sebanyak 6 sampel diberi tanda dan diukur tingginya sebelum di-proofing) kemudian dilakukan proofing pada suhu $55^{\circ} \mathrm{C}$ selama 1 jam.
Adonan yang telah mengembang digoreng pada suhu penggorengan $160^{\circ} \mathrm{C}$ hingga diperoleh produk berwarna kuning keemasan (sebanyak 6 sampel bertanda diukur tingginya setelah digoreng). Donat dianalisa fisiko kimianya meliputi kadar air, kadar lemak, ALB, PV dan kadar karoten dengan mengacu pada metode standar MPOB (MPOB, 2004) serta uji organoleptik.

\section{Pembuatan Bolu Gulung}

Bolu gulung dibuat dengan formula standar yang dimiliki oleh PPKS namun margarin dan baking shortening komersial diganti menggunakan margarin dan baking shortening menggunakan MSM (MSM NPO atau MSM TBS) seperti yang disajikan pada Tabel 4. Bahan baku dicampurkan dalam mixer hingga kalis.

Tabel 3. Formulasi donat $(1 \mathrm{~kg}$ ) menggunakan margarin dan baking shortening MSM

\begin{tabular}{|c|c|c|c|c|c|}
\hline $\begin{array}{l}\text { Bahan adonan donat } \\
\text { Bahan adonan donat }\end{array}$ & $\begin{array}{l}\text { Formula } 1 \text { (kontrol) } \\
\text { formula PPKS }\end{array}$ & $\begin{array}{l}\text { Formula } 2 \\
\text { formula PPKS }\end{array}$ & $\begin{array}{l}\text { Formula } 3 \\
\text { formula PPKS }\end{array}$ & $\begin{array}{l}\text { Formula } 4 \\
\text { formula PPKS }\end{array}$ & $\begin{array}{l}\text { Formula } 5 \\
\text { formula PPKS }\end{array}$ \\
\hline Margarin komersial (g) & 30 & - & - & - & - \\
\hline Margarin MSM NPO grade A $(\mathrm{g})$ & - & 30 & - & - & - \\
\hline Margarin MSM NPO grade B (g) & - & - & 30 & - & - \\
\hline -Magarin MSM TBS grade A (g) & - & - & - & 30 & - \\
\hline Margarin MSM TBS grade B (g) & - & - & - & - & 30 \\
\hline Baking shortening komersial (g) & 13 & - & - & - & - \\
\hline Baking shortening MSM NPO grade A (g) & - & 13 & - & - & - \\
\hline Baking shortening MSM NPO grade B $(\mathrm{g})$ & - & - & 13 & - & - \\
\hline Baking shortening MSM TBS grade A (g) & - & - & - & 13 & - \\
\hline Baking shortening MSM TBS grade B (g) & - & - & - & - & 13 \\
\hline
\end{tabular}

Keterangan: singkatan dapat dilihat pada Tabel 1 
Tabel 4. Formulasi bolu gulung (1 adonan) menggunakan margarin dan baking shortening MSM

\begin{tabular}{llllll}
\hline Bahan adonan bolu gulung & $\begin{array}{l}\text { Formula 1 (kontrol) } \\
\text { formula PPKS }\end{array}$ & $\begin{array}{l}\text { Formula 2 } \\
\text { formula PPKS }\end{array}$ & $\begin{array}{l}\text { Formula 3 } \\
\text { formula PPKS }\end{array}$ & $\begin{array}{l}\text { Formula } 4 \\
\text { formula PPKS }\end{array}$ & $\begin{array}{l}\text { Formula } 5 \\
\text { formula PPKS }\end{array}$ \\
\hline Margarin komersial $(\mathrm{g})$ & 500 & - & - & - & - \\
Margarin MSM NPO grade A $(\mathrm{g})$ & - & 500 & - & - & - \\
Baking shortening MSM NPO grade B $(\mathrm{g})$ & - & - & 500 & - & - \\
Magarin MSM TBS grade A (g) & - & - & - & 500 & - \\
Baking shortening MSM TBS grade B $(\mathrm{g})$ & - & - & - & - & 500 \\
\hline
\end{tabular}

Keterangan: singkatan dapat dilihat pada Tabel 1

Selanjutnya adonan dimasukkan ke dalam loyang dengan ukuran panjang $36 \mathrm{~cm}$, lebar $28 \mathrm{~cm}$ dan tinggi $3,5 \mathrm{~cm}$ (sebanyak 4 loyang diberi tanda dan diukur tingginya sebelum dipanggang). Adonan dipanggang ke dalam oven pada suhu $150{ }^{\circ} \mathrm{C}$ selama 30 menit (sebanyak 4 sampel bertanda diukur tingginya setelah dipanggang). Bolu gulung dianalisa fisiko kimianya meliputi kadar air, kadar lemak, ALB, PV dan kadar karoten dengan mengacu pada metode standar MPOB (MPOB, 2004) serta uji organoleptik.

\section{Uji Organoleptik}

Uji organoleptik dilakukan kepada 25 orang panelis untuk menilai penerimaan terhadap kenampakan warna, aroma, tekstur dan rasa roti manis, donat dan bolu gulung mengggunakan metode hedonik (uji kesukaan) pada skala penilaian 1-5 yaitu (1) tidak suka, (2) kurang suka, (3) cukup suka, (4) suka, dan (5) sangat suka.

\section{HASIL DAN PEMBAHASAN}

\section{Margarin dan Baking Shortening Minyak Sawit Merah (MSM)}

Kadar asam lemak bebas (ALB) dan bilangan peroksida disajikan pada Gambar 1. Kadar ALB margarin dan baking shortening $(>0,1 \%)$ relatif tinggi. Sebagai pembanding, produk rafinasi minyak sawit seperti RBDPOlein dipersyaratkan kadar ALB maksimum sebesar 0,1\% (SNI 01-0018-2006, Badan Standardisasi Nasional (2006)). Namun demikian, berdasarkan SNI 7709: 2012 (Badan Standardisasi Nasional, 2012), kadar ALB pada minyak goreng maksimum 0,3\%. Tingginya, kadar ALB pada margarin dan baking shortening dikarenakan bahan baku meliputi MSM, RBDPO, RBDPS dan RBDPKO memiliki ALB relatif tinggi. Peningkatan kadar ALB juga dapat terjadi karena adanya pemanasan pada saat pencampuran bahan dalam pembuatan margarin dan baking shortening. Bilangan peroksida margarin dan baking shortening relatif rendah $(1,35-3,00 \mathrm{mgeq} / \mathrm{kg})$.

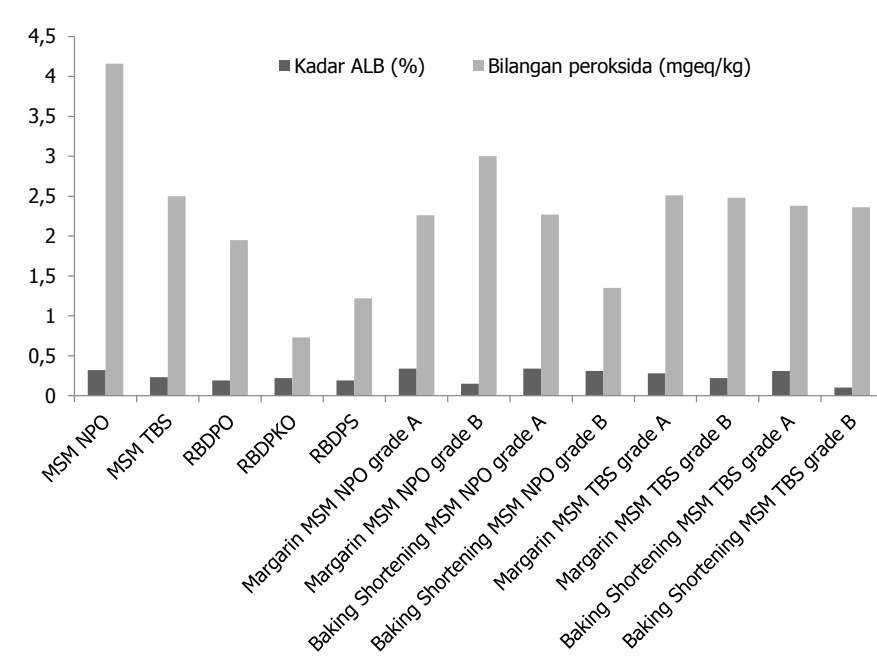

Gambar 1. Kadar asam lemak bebas dan bilangan peroksida bahan baku, margarin dan baking shortening

Keterangan: singkatan dapat dilihat pada Tabel 1

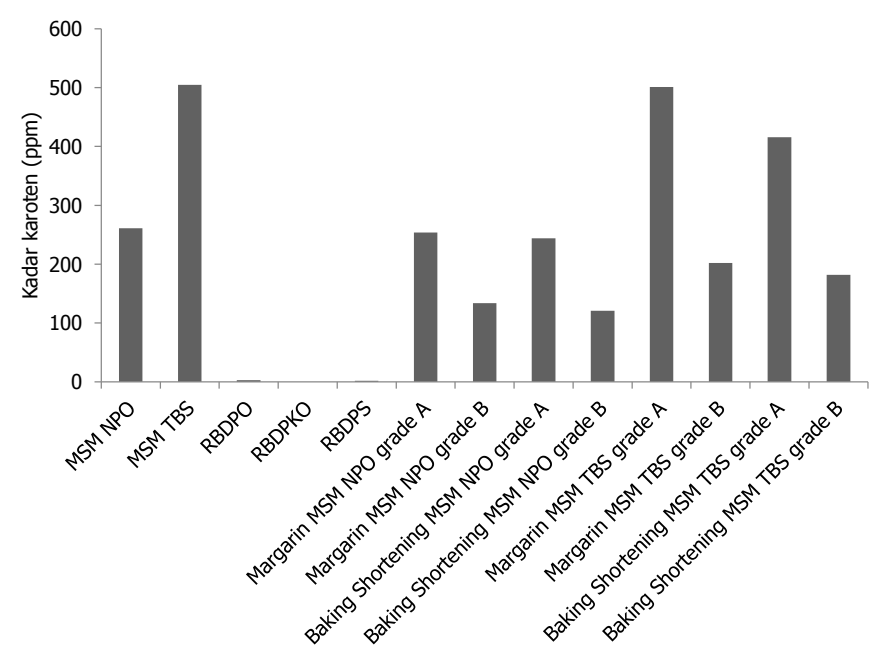

Gambar 2. Kadar karoten bahan baku, margarin dan baking shortening

Keterangan: singkatan dapat dilihat pada Tabel 1 
Nilai ini memenuhi syarat beberapa produk pembanding seperti minyak goreng yaitu maksimum sebesar 10 mgeq/kg (SNI 7709: 2012, Badan Standardisasi Nasional (2012)). Bilangan peroksida tinggi dapat mempercepat terjadinya oksidasi yang akan menghasilkan ketengikan pada produk.

Kadar karoten disajikan pada Gambar 2. Kadar karoten margarin dan baking shortening menggunakan MSM NPO sebesar 121-254 ppm lebih rendah dibandingkan menggunakan MSM TBS (182-501 ppm). Hal ini dikarenakan MSM NPO memiliki karoten lebih rendah (261 ppm) dibandingkan MSM TBS (505 ppm). Margarin dan baking shortening yang terbuat dari MSM dan RBDPO, RBDPS atau RBDPKO mengandung karoten lebih rendah dibandingkan menggunakan MSM $100 \%$, karena ketiga bahan baku tersebut mengandung karoten rendah masing-masing sebesar 3, 0 dan 2 ppm. MSM NPO memiliki karoten yang rendah dikarenakan pada proses pembuatannya CPO mengalami proses pemanasan dan pencucian menggunakan air untuk menghilangkan sabun dan natrium tersisa. Meskipun demikian, margarin dan baking shortening terbuat dari MSM baik NPO maupun TBS mengandung nutrisi yang tinggi. Menurut Rice dan Burns (2010) bahwa MSM mengandung senyawa fitonutrien berupa karoten (pro vitamin A), tokoferol dan tokotrienol yang cukup tinggi. Oleh karena itu, MSM dapat menggantikan penggunaan pewarna sintetis dan juga mampu melengkapi kandungan vitamin pada produk margarin (Hasibuan dan Siahaan, 2014).
Kandungan lemak padat margarin dan baking shortening disajikan pada Tabel 5. Kandungan lemak padat merupakan sifat fisik yang menjelaskan jumlah fraksi padatan dalam minyak/lemak pada suhu tertentu yang mempengaruhi sifat fisik seperti kemampuan oles, profil pelelehan, konsistensi, stabilitas, dan pengaruh sifat sensori. Kandungan lemak padat pada MSM TBS yang digunakan lebih rendah dibandingkan MSM NPO. Adanya penambahan RBDPO pada MSM TBS cenderung meningkatkan kandungan lemak padat pada setiap suhu pengukuran. Sedangkan penambahan RBDPO pada MSM NPO tidak merubah kandungan lemak padatnya dikarenakan profil RBDPO dan MSM NPO relatif sama. Kandungan lemak padat pada baking shortening yang lebih tinggi terjadi dikarenakan MSM dicampur dengan RBDPS dan RBDPKO. RBDPS merupakan fraksi minyak sawit yang memiliki titik leleh tinggi sehingga wujudnya keras (Hasibuan, 2012; Hasibuan dan Siahaan, 2013). Namun demikian, pada suhu $30-40{ }^{\circ} \mathrm{C}$ kandungan lemak padat diatur agar tidak tinggi (seperti profil RBDPS) dengan penambahan RBDPKO yang memiliki kandungan lemak padat pada suhu $30-40{ }^{\circ} \mathrm{C}$ rendah (0).

Profil kandungan lemak padat dipengaruhi oleh komposisi asam lemak serta distribusi asam lemak pada struktur trigliserida. Komposisi asam lemak margarin baik menggunakan MSM NPO dan MSM TBS ataupun campurannya dengan RBDPO relatif tidak berbeda jauh (Tabel 6). Komposisi asam lemak baking shortening berbeda dengan MSM pada asam laurat, asam miristat,

Tabel 5. Kandungan lemak padat bahan baku, margarin dan baking shortening

\begin{tabular}{|c|c|c|c|c|c|c|}
\hline \multirow{2}{*}{ Sampel } & \multicolumn{6}{|c|}{ Kandungan lemak padat (\%) pada suhu } \\
\hline & $10^{\circ} \mathrm{C}$ & $20^{\circ} \mathrm{C}$ & $25^{\circ} \mathrm{C}$ & $30^{\circ} \mathrm{C}$ & $35^{\circ} \mathrm{C}$ & $40^{\circ} \mathrm{C}$ \\
\hline MSM NPO & 50,1 & 24,2 & 18,7 & 9,9 & 6,2 & 3,5 \\
\hline MSM TBS & 57,8 & 23,5 & 14,1 & 5,1 & 3,1 & 1,6 \\
\hline RBDPO & 54,7 & 26,4 & 17,7 & 10,0 & 6,7 & 3,6 \\
\hline RBDPKO & 62,2 & 39,5 & 19,6 & 0 & 0 & 0 \\
\hline RBDPS & 84,9 & 70,8 & 68,5 & 51,7 & 42,1 & 32,8 \\
\hline Margarin MSM NPO grade A & 52,7 & 25,5 & 18,9 & 9,6 & 6,5 & 3,6 \\
\hline Margarin MSM NPO grade B & 49,6 & 24,4 & 18,0 & 9,1 & 5,4 & 2,9 \\
\hline Baking Shortening MSM NPO grade A & 52,0 & 25,9 & 20,0 & 10,8 & 6,7 & 4,2 \\
\hline Baking Shortening MSM NPO grade B & 46,6 & 23,5 & 17,8 & 9,7 & 5,7 & 3,4 \\
\hline Margarin MSM TBS grade A & 58,3 & 25,3 & 13,7 & 5,2 & 2,9 & 0,8 \\
\hline Margarin MSM TBS grade B & 57,3 & 26,6 & 17,2 & 8,1 & 5,3 & 2,8 \\
\hline Baking Shortening MSM TBS grade A & 60,1 & 26,5 & 21,3 & 9,4 & 5,3 & 2,9 \\
\hline Baking Shortening MSM TBS grade B & 59,4 & 29,2 & 17,6 & 11,3 & 7,2 & 4,3 \\
\hline
\end{tabular}

Keterangan: singkatan dapat dilihat pada Tabel 1 
Tabel 6. Komposisi asam lemak bahan baku, margarin dan baking shortening

\begin{tabular}{|c|c|c|c|c|c|c|c|c|c|c|c|c|}
\hline \multirow{2}{*}{ Sampel } & \multicolumn{12}{|c|}{ Komposisi asam lemak (\%) } \\
\hline & C8:0 & $\mathrm{C} 10: 0$ & C12:0 & C14:0 & C16:0 & C16:1 & C18:0 & C18:1 & C18:2 & C18:3 & C20:0 & C20:1 \\
\hline MSM NPO & - & - & 0,2 & 0,9 & 45,7 & 0,1 & 3,9 & 40,0 & 8,6 & 0,2 & 0,3 & 0,1 \\
\hline MSM TBS & - & - & 0,2 & 0,9 & 44,3 & 0,1 & 3,3 & 39,6 & 10,9 & 0,2 & 0,2 & 0,1 \\
\hline RBDPO & - & - & 0,2 & 0,9 & 45,7 & 0,1 & 3,9 & 39,7 & 8,9 & 0,1 & 0,3 & 0,1 \\
\hline RBDPKO & 3,6 & 3,2 & 47,8 & 16,3 & 8,7 & - & 2,1 & 15,7 & 2,2 & 0,1 & 0,1 & - \\
\hline RBDPS & - & - & 0,2 & 1,1 & 64,1 & 0,1 & 4,5 & 24,4 & 4,6 & 0,1 & 0,3 & 0,1 \\
\hline Margarin MSM NPO grade A & - & - & 0,2 & 0,9 & 45,9 & 0,1 & 3,8 & 39,6 & 8,8 & 0,2 & 0,3 & 0,1 \\
\hline Margarin MSM NPO grade B & - & - & 0,2 & 0,9 & 45,4 & 0,1 & 3,9 & 40,4 & 8,6 & 0,2 & 0,3 & 0,1 \\
\hline $\begin{array}{l}\text { Baking shortening MSM NPO } \\
\text { grade A }\end{array}$ & 0,4 & 0,4 & 5,8 & 2,7 & 434 & 0,1 & 3,8 & 35,7 & 7,2 & 0,1 & 0,3 & 0,1 \\
\hline $\begin{array}{l}\text { Baking shortening MSM NPO } \\
\text { grade B }\end{array}$ & 0,5 & 0,5 & 7,3 & 3,2 & 41,4 & 0,1 & 3,8 & 35,2 & 7,5 & 0,1 & 0,2 & 0,1 \\
\hline Margarin MSM TBS grade A & - & - & 0,2 & 0,9 & 44,3 & 0,1 & 3,3 & 39,6 & 10,9 & 0,2 & 0,2 & 0,1 \\
\hline Margarin MSM TBS grade B & - & - & 0,3 & 0,9 & 46,4 & 0,1 & 3,6 & 38,7 & 9,3 & 0,2 & 0,3 & 0,1 \\
\hline $\begin{array}{l}\text { Baking shortening MSM TBS } \\
\text { grade A }\end{array}$ & 0,4 & 0,3 & 5,4 & 2,6 & 44,1 & 0,1 & 3,5 & 34,1 & 8,9 & 0,2 & 0,2 & 0,1 \\
\hline $\begin{array}{l}\text { Baking shortening MSM TBS } \\
\text { grade B }\end{array}$ & 0,3 & 0,3 & 4,2 & 2,2 & 45,6 & 0,1 & 3,6 & 35,2 & 8,1 & 0,1 & 0,3 & - \\
\hline
\end{tabular}

Keterangan: singkatan dapat dilihat pada Tabel 1

asam palmitat dan asam oleat, hal ini disebabkan oleh penambahan bahan lain berupa RBDPS dan RBDPKO. RBDPS merupakan fraksi minyak sawit yang mengandung asam palmitat tinggi (Hasibuan, 2012) sementara RBDPKO mengandung asam laurat tinggi (Hasibuan dkk., 2012). Penambahan RBDPKO pada baking shortening dimaksudkan untuk melembutkan produk adonan bakery.

\section{Aplikasi Margarin dan Baking Shortening Minyak Sawit Merah dalam Produk Bakery}

\section{Pengembangan Adonan Produk Bakery}

Pengembangan adonan ditentukan dengan kenaikan tinggi produk bakery. Kenaikan tinggi roti manis, donat dan bolu gulung disajikan pada Gambar 3. Margarin dan baking shortening menggunakan MSM NPO dan MSM TBS tidak sebaik produk komersial dalam meningkatkan tinggi produk bakery. Secara umum, ketiga produk bakery yang menggunakan margarin dan baking shortening MSM TBS (formula 4) cenderung lebih baik dalam meningkatkan tinggi produk dibandingkan MSM NPO (formula 2). MSM NPO yang dicampur dengan RBDPO (formula 3) cenderung lebih baik dalam meningkatkan tinggi roti manis dan donat dibandingkan MSM 100\% (formula 2). Sedangkan pada MSM TBS yang dicampur RBDPO tidak sebaik MSM $100 \%$ untuk kenaikan tinggi roti manis dan donat. Margarin dan baking shortening yang menggunakan MSM TBS : RBDPO (formula 5) cenderung memberikan kenaikan tinggi roti manis lebih tinggi dibandingkan MSM NPO : RBDPO namun sebaliknya pada donat. Kenaikan tinggi bolu gulung yang menggunakan margarin dari MSM NPO dan MSM TBS dan baking shortening MSM NPO : RBDPO dan MSM TBS : RBDPO memberikan kenaikan tinggi yang relatif sama dengan kisaran $0,55-0,57 \mathrm{~cm}$. Hasibuan dan Hardika (2015) telah melaporkan bahwa kenaikan tinggi bolu gulung dengan menggunakan margarin dengan bahan tambahan MSM dapat mencapai $0,9 \mathrm{~cm}$ sedangkan menggunakan margarin komersial mencapai $0,7 \mathrm{~cm}$.

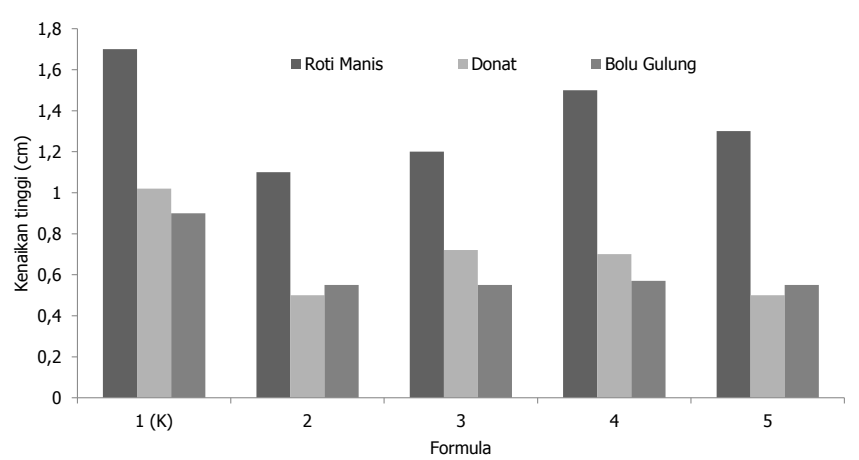

Gambar 3. Kenaikan tinggi produk bakery

Keterangan: $\mathrm{K}=$ kontrol 


\section{Mutu Produk Bakery}

\section{Kadar air}

Air merupakan komponen penting dalam bahan makanan karena air dapat mempengaruhi penampakan, tekstur, serta cita rasa makanan. Kandungan air dalam bahan makanan menentukan penerimaan, kesegaran, dan daya tahan bahan tersebut (Winarno, 2004). Kadar air pada roti manis, donat dan bolu gulung masingmasing berkisar antara 18,12-22,11\%, 18,00-23,86\% dan 9,80-18,49\% (Tabel 7). Kisaran kadar air yang cukup lebar pada setiap perlakuan diduga disebabkan oleh berbedanya homogenitas adonan pada saat proses pencampuran dan pemanggangan (roti manis dan bolu gulung) atau penggorengan (donat) yang tidak merata. Dalam proses pembuatan adonan ditambahkan air dan diduga terperangkap dalam bahan lain seperti tepung dan lainnya secara tidak merata. Kadar air pada produk dipengaruhi oleh margarin dan baking shortening yang digunakan. Margarin mengandung air cukup tinggi dan berdasarkan formula sebesar $15,8 \%$ sedangkan baking shortening relatif rendah.

\section{Kadar lemak}

Lemak pada produk bakery diperoleh dari margarin dan atau baking shortening, susu bubuk dan kuning telur. Roti manis, donat dan bolu gulung masingmasing mengandung lemak sebesar 13,80-15,82\%, 39,60-46,93\% dan 42,10-45,96\% (Tabel 7). Sama halnya dengan kadar air, kadar lemak pada formula roti relatif lebar dikarenakan homogenitas pada saat pencampuran dan pengadukan adonan.

\section{Kadar asam lemak bebas (ALB)}

Lemak pada roti manis, donat dan bolu gulung masing-masing mengandung ALB sebesar 0,49-0,75\%, 0,10-0,84\%, dan 0,26-0,828\% (Table 8). Ditinjau dari bahan bakunya (Gambar 1), aplikasi margarin dan baking shortening menjadi produk bakery cenderung meningkatkan ALB. Hal ini dikarenakan oleh adanya penambahan air dan ragi (roti manis dan donat) pada adonan serta dipanggang atau digoreng pada suhu tinggi. Kerusakan minyak atau lemak dapat juga diakibatkan oleh proses oksidasi, yaitu terjadinya kontak antara sejumlah oksigen dengan minyak atau lemak, yang biasanya dimulai dengan pembentukan peroksida dan hidroperoksida. Selanjutnya asam lemak terurai disertai dengan hidroperoksida menjadi aldehid dan keton serta ALB. Lemak dengan kadar ALB lebih dari $1 \%$, jika dicicipi akan terasa membentuk film pada permukaan lidah dan tidak berbau tengik, namun intensitasnya tidak bertambah dengan bertambahnya jumlah ALB (Ketaren, 2008).

\section{Bilangan peroksida}

Roti manis, donat dan bolu gulung mengandung lemak yang memiliki bilangan peroksida masing-masing sebesar 0,17-0,36, 0,11-0,33, 0,02-0,55 mgeq/kg (Tabel 8). Bilangan peroksida produk bakery tersebut relatif rendah yang menandakan lemak atau minyak mengalami proses oksidasi cukup rendah. Rendahnya bilangan peroksida tidak menimbulkan bau tengik pada produk bakery. Ditinjau dari bahan bakunya (Gambar 1), aplikasi margarin dan baking shortening dari MSM tidak mengalami oksidasi yang berlebihan akibat dari proses pemanasan saat pemanggangan atau penggorengan pada suhu tinggi.

\section{Kadar karoten}

Donat mengandung kadar karoten relatif lebih rendah dibandingkan roti manis dan bolu gulung (Tabel 8), hal ini disebabkan oleh penggunaan margarin dan baking shortening pada adonan lebih rendah. Margarin dan baking shortening yang terbuat dari MSM TBS cenderung memberikan kadar karoten lemak lebih tinggi dibandingkan MSM NPO, karena pada bahan bakunya juga lebih tinggi (Gambar 2). Produk bakery yang dihasilkan menggunakan MSM TBS berwarna lebih merah

Tabel 7. Kadar air dan kadar lemak produk bakery

\begin{tabular}{lllllll}
\hline Formula & Kadar air (\%) & \multicolumn{5}{c}{ Kadar lemak (\%) } \\
& Roti manis & Donat & Bolu gulung & Roti manis & Donat & Bolu gulung \\
\hline $1($ K $)$ & 19,74 & 19,55 & 12,19 & 14,15 & 41,57 & 45,96 \\
2 & 22,11 & 21,02 & 18,49 & 14,47 & 46,93 & 43,45 \\
3 & 21,00 & 23,86 & 13,12 & 15,82 & 44,55 & 45,63 \\
4 & 18,12 & 23,40 & 10,10 & 13,80 & 41,50 & 43,60 \\
5 & 19,74 & 18,00 & 9,80 & 14,10 & 39,60 & 42,10 \\
\hline
\end{tabular}

Keterangan: $\mathrm{K}=$ kontrol 
Tabel 8. Kadar ALB, bilangan peroksida dan kadar karoten lemak pada produk bakery

\begin{tabular}{llllllllll}
\hline \multirow{2}{*}{ Formula } & \multicolumn{3}{c}{ Kadar ALB (\%) } & \multicolumn{3}{c}{ Bilangan peroksida (meq/kg) } & \multicolumn{3}{c}{ Kadar karoten (ppm) } \\
\cline { 2 - 9 } & Roti manis & Donat & Bolu gulung & Roti manis & Donat & Bolu gulung & Roti manis & Donat & Bolu gulung \\
\hline $1(\mathrm{~K})$ & 0,55 & 0,33 & 0,72 & 0,18 & 0,25 & 0,29 & 30 & 10 & 52 \\
2 & 0,75 & 0,19 & 0,80 & 0,23 & 0,11 & 0,19 & 54 & 24 & 40 \\
3 & 0,55 & 0,61 & 0,82 & 0,17 & 0,33 & 0,55 & 54 & 9 & 48 \\
4 & 0,59 & 0,84 & 0,47 & 0,27 & 0,28 & 0,02 & 211 & 34 & 246 \\
5 & 0,49 & 0,10 & 0,26 & 0,36 & 0,17 & 0,22 & 124 & 27 & 146 \\
\hline
\end{tabular}

Keterangan: $\mathrm{K}=$ kontrol

dibandingkan MSM NPO. Apabila ditinjau dari bahan baku menunjukkan bahwa proses pemanggangan atau penggorengan cenderung menurunkan kadar karoten. Hal ini disebabkan oleh karoten merupakan senyawa yang mudah terdegradasi oleh panas, udara dan cahaya (Hasibuan dkk., 2013). Oksidasi dari $\beta$-karoten dapat menyebabkan flavor alami hilang dan dekomposisi dari kromofor makanan yang membuat produk kurang dapat diterima oleh konsumen (Jia dkk., 2007).

\section{Uji Organoleptik}

Penerimaan terhadap warna, tekstur, aroma dan rasa roti manis, donat dan bolu gulung disajikan pada Gambar 4. Nilai rerata tingkat kesukaan roti manis menggunakan margarin dan baking shortening MSM NPO dan MSM TBS berkisar pada penilaian agak suka kecuali pada formula roti manis 2 terhadap aroma yang bernilai kurang suka. Nilai ini relatif menyerupai penerimaan kesukaan roti manis menggunakan margarin dan baking shortening komersial. Roti manis yang menggunakan margarin dan baking shortening MSM NPO:RBDPO cenderung lebih disukai dibandingkan hanya MSM NPO saja, hal yang sama juga pada MSM TBS.

Nilai rerata tingkat kesukaan donat menggunakan MSM NPO dan MSM TBS relatif rendah dibandingkan produk yang dihasilkan dengan margarin dan baking shortening komersial. Penerimaan donat yang menggunakan margarin dan baking shortening MSM NPO juga relatif menyerupai MSM TBS. Hal ini diduga oleh karena karakteristik (tekstur, warna, aroma dan rasa) keempat formula donat (formula 2 hingga 5) yang hampir sama. Di samping itu juga disebabkan oleh penggunaan margarin dan baking shortening relatif rendah sehingga perubahan warna dan teksturnya donat tidak begitu tampak berbeda yang dibuktikan juga dengan kadar karoten lemak pada donat cukup rendah (Tabel 8).

Nilai kesukaan bolu gulung menggunakan margarin dan baking shortening MSM NPO dan MSM TBS relatif
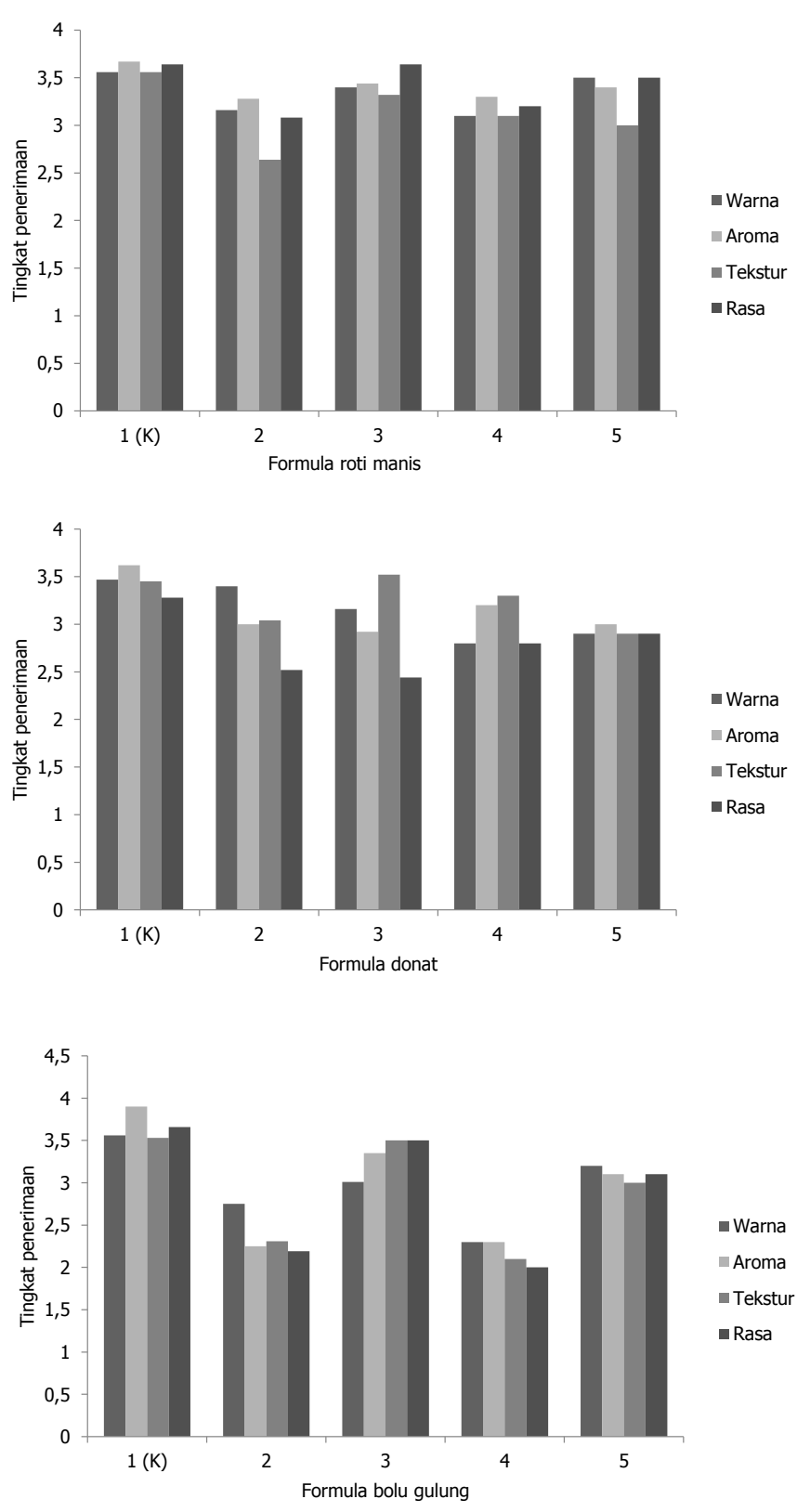

Gambar 4. Tingkat penerimaan produk bakery

Keterangan: $\mathrm{K}=$ kontrol 
lebih rendah dibandingkan margarin komersial. Nilai penerimaan bolu gulung dengan margarin dan baking shortening komersial berkisar 3,53-3,90 (agak suka). Nilai ini relatif lebih rendah dibandingkan yang telah dilaporkan oleh Hasibuan dan Hardika (2015) dengan nilai > 4,00 (suka). Hal ini diduga disebabkan oleh panelis terpangaruh dalam memberikan penilaian karena formula 2 hingga 5 berwarna lebih merah dan agak berbau khas karoten dari MSM. Sedangkan margarin komersial umumnya menggunakan karoten alami ataupun sintetik dalam bentuk konsentrat (Hasibuan dan Hardika, 2015). Sama halnya dengan roti manis, bolu gulung yang menggunakan margarin dan baking shortening MSM NPO atau TBS yang dicampur dengan RBDPO cenderung menghasilkan penerimaan kesukaan relatif lebih tinggi dibandingkan menggunakan MSM $100 \%$.

\section{KESIMPULAN}

Minyak sawit merah (MSM) dapat dimanfaatkan sebagai bahan baku menjadi margarin dan baking shortening namun perlu dicampur dengan RBDPO agar diperoleh produk yang tidak terlalu merah dan berbau khas karoten seperti bahan bakunya CPO. Aplikasi margarin dan baking shortening MSM NPO dan MSM TBS yang dicampur dengan RBDPO pada roti manis, donat dan bolu gulung memiliki karakteristik menyerupai produk yang menggunakan margarin dan baking shortening komersial. Sesuai hasil uji hedonik menunjukkan bahwa roti manis, donat berbasis MSM dapat diterima oleh panelis berdasarkan parameter warna, aroma, tekstur dan rasa.

\section{DAFTAR PUSTAKA}

Andarwulan, N., Adawiyah, D.R., Wulandari, N., Hariyadi, P., Triana, R.N., Affandi, A.R., Nur, R.C., Tjahjadi, S. dan Ellen, M.F. (2014). Aplikasi margarin minyak sawit merah pada produk pound cake dan roti manis. Prosiding Seminar Hasil-Hasil PPM IPB 2014. ISBN: 978-6028853-22-4. Bogor I: 192-206.

Alyas, S.A., Abdullah, A. dan Idris, N.A. (2006). Changes of $\beta$-carotene content during heating of red palm olein. Journal of Palm Oil Research Special Issue-April 2006: 99-102.

Ayeleso, A.O., Oguntibeju, O.O. dan Brooks, N.L. (2012). Effects of dietary intake of red palm oil on fattly acid composition and lipid profiles in male wistar rats. African Journal of Biotechnology 11: 8275-8279.

Badan Standardisasi Nasional. (2006). Refined Bleached Deodorized Palm Olein. SNI 01-0018-2006.
Badan Standardisasi Nasional. (2012). Minyak Goreng. SNI 7709:2012.

Elisabeth, J.E. (2009). Pengalaman industri kelapa sawit dalam diversifikasi produk olahan hilir. Prosiding Pertemuan Teknis Kelapa Sawit 2009 Jakarta Convention Centre 2830 Mei 2009. Hal. 95 - 103.

Hasibuan, H.A., Siahaan, D., Rivani, M. dan Panjaitan, F.R. (2009). Minyak sawit dan minyak inti sawit sebagai bahan baku formulasi plastic fat dan specialty fat. Prosiding Pertemuan Teknis Kelapa Sawit Jakarta Convention Centre 28-30 Mei 2009. Jakarta. Hal: 295-306.

Hasibuan, H.A. (2012). Kajian mutu dan karakteristik minyak sawit Indonesia serta produk fraksinasinya. Jurnal Standardisasi 14: 13-21.

Hasibuan, H.A., Siahaan, D. dan Sunarya. (2012). Kajian karakteristik minyak inti sawit Indonesia dan produk fraksinya terkait dengan amandemen standar Codex. Jurnal Standardisasi 14: 98-104.

Hasibuan, H.A. dan Siahaan, D. (2013). Karakteristik Cpo, Minyak Inti Sawit dan Fraksinya. Seri Buku Saku 30. PPKS. Medan.

Hasibuan, H.A., Rivani, M. dan Lubis, A. (2013). Studi stabilitas $\beta$-karoten yang digunakan sebagai bahan fortifikasi minyak goreng kelapa sawit. Warta Pusat Penelitian Kelapa Sawit 18: 91-95.

Hasibuan, H.A. dan Siahaan, D. (2014). Review standar minyak goreng sawit diperkaya karoten terkait fortifikasi vitamin A sebagai revisi SNI 031-3741-2002. Jurnal Standardisasi 16: 65-76.

Hasibuan, H.A. dan Hardika, A.P. (2015). Formulasi dan pengolahan margarin menggunakan fraksi minyak sawit pada skala industri kecil serta aplikasinya dalam pembuatan bolu gulung. Agritech 35: 377-386.

Hasibuan, H.A. dan Magindrin. (2015). Pengembangan proses pengolahan shortening berbahan minyak sawit pada skala industri kecil kapasitas $50 \mathrm{~kg} /$ batch. Warta Hasil Penelitian Industri 32: 24-32.

Hasibuan, H.A. (2016). Retensi karoten dan retinol palmitat pada minyak goreng dan produk gorengannya. Jurnal Penelitian Kelapa Sawit 24: 147-159.

Jia, M., Kim, H.J. dan Min, D.B. (2007). Effects of soybean oil and oxidized soybean oil on the stability of $\beta$-carotene. Food Chemistry 103: 695-700.

Ketaren, S. (2008). Pengantar Teknologi Minyak dan Lemak Pangan. UI-Press, Jakarta.

Manorama, K. (2014). Potential use of red palm oil in combating vitamin A deficinecy in India. Indian Journal of Community Health 26: 45-53.

Malaysian Palm Oil Board (MPOB). (2004). MPOB Test Method: A Compendium of Test on Palm Oil Products, Palm Kernel Products, Fatty Acids, Food Related Products and Others. Malaysia. 
Rice, A.L. dan Burns, J.B. (2010). Moving from efficacy to effectiveness: red palm oil's role in preventing vitamin $A$ deficiency. Journal of the American College of Nutrition 29: 302S-313S.

Robiyansyah, A., Zuidar, S. dan Hidayati. S. (2017). Pemanfaatan minyak sawit merah dalam pembuatan biskuit kacang kaya beta karoten. Jurnal teknologi Industri dan Hasil Pertanian 22: 11-20.

Sahri, M.M. dan Idris, N.A. (2010). Palm stearin as low trans hard stock for margarine. Sains Malaysiana 39: 821-827.
Siahaan, D., Hasibuan, H.A., Rivani, M. dan Panjaitan, F.R. (2008). Karakteristik CPO Indonesia. Warta Pusat Penelitian Kelapa Sawit 16: 27-37.

Siahaan, D., Sianipar, N., dan Manurung, H. (2013). Pengembangan proses pembuatan pastry shortening berbahan baku fraksi-fraksi minyak kelapa sawit. Warta Pusat Penelitian Kelapa Sawit 1: 25-36.

Winarno, F.G. (2004). Kimia Pangan Gizi. Edisi Kedua. PT. Gramedia Pustaka Utama. Jakarta. 